\title{
Islam and its Role in Building Society: An Objective Study
}

\author{
Dr. Majid Ragab Al-Abed Sukar \\ Associate Professor of Interpretation and Quranic Sciences \\ Al-Aqsa University, Palestine \\ Email: majed2006m [AT] hotmail.com \\ Quranic study \\ In the name of of Allah the Merciful
}

Praise be to God, Lord of the worlds, and prayers and peace be upon the most honorable messengers, Muhammad, may God bless him and his family and companions as a whole.

\begin{abstract}
----
God sent His Prophet Muhammad, may God bless him and grant him peace, with guidance and the religion of truth, to guide humanity to goodness and guidance, and to build an interdependent Islamic society that loves each other, through the tolerance of Islam that focused on the first building block of society, namely the family, if the rest of society is reconciled. And if it spoiled the rest of society.
\end{abstract}

In this study, we will shed light on the Islamic directives for building this majestic societal edifice through what was stated in the Qur'an and supported by the pure Sunnah.

By God, I ask that he help me through this effort to help my nation, and that God accepts it sincerely for the honorable face.

First: The importance of the topic

The importance of this research stems from the following points

1) Family disintegration in the West, despite the urbanization they praise

2) Demonstrate the power and tolerance of Islam in building the Muslim family, and then the Muslim community.

3) Show the true face of true Islam, which calls for virtue and rejects vice

Second: Reasons for choosing the topic

The following reasons are among the most important reasons that prompted the researcher to choose this topic for research:

1) fierce attack on Islam, describing it as terrorism, as a falsehood.

2) The great importance of this issue to the Islamic Ummah, as it contributes to building the Muslim community.

3) The strong desire to tolerate Islam for those who do not know it from the West.

Third: The aims and objectives of the study

This study has many goals and multiple goals, including

1) 1)Shedding light on the importance of this issue, in the desire to increase the interest of the preachers in order to advance the Muslim community.

2) Explain the virtue of the call to God, and its role in building and leading the Islamic nation. 


\section{Fourth: The research problem}

1) There are people who have not reached Islam yet.

2) There are people who know Islam as an abstract ritual.

3) There is a fierce attack to distort Islam and tarnish the image of Muslims, and it has. entered all homes, such as satellite channels and the Internet.

4) Western family disintegration and lack of attention to family members.

\section{Fifth: The research methodology and the nature of work in it}

In this study, the researcher adopted - with the help of God Almighty - the descriptive analytical approach, as it is the most appropriate approach to such a topic, by presenting the relevant verses and analyzing them and indicating the implications contained therein through various interpretations.

\section{Sixth: Research plan}

The researcher developed a plan for this research, so he made it into an introduction, seven topics and a conclusion as follows

\section{INTRODUCTION}

It includes the importance of research, the reasons for choosing it, the aims and purpose of the study, the research problem, the research methodology and the nature of work in it, and the research plan

\section{The first topic: features of the relationship with parents}

The righteousness of the parents is one of the greatest and greatest rights of the servants that God Almighty commanded to take care of, and Islam raised the position of the parents, to a level that humanity did not know in any other than this religion, the true Islamic religion, where God made him $\square$ in the rank that follows his right - glory be to Him - in monotheism And he made the parental consent of God after the pleasing of God Y and made charity towards them a virtue that follows the virtue of faith in him, and this was represented in the Almighty saying: [Worship God and do not share anything with him and with the kindness of goodness] \{Women: 36\}

The Holy Qur'an transcends the depiction of the status of parents, embodying the spirit of love, interdependence and cohesion by defining the features of high-level dealing, which a Muslim should follow in his treatment of them, if one or both of them reached the age of seniority, reaching the goal that humanity did not know in other than this religion religion, as evidenced by the verse: [spent your Lord not none but him and dutiful to your parents either they reach old age you have one or both of them, do not say $\mathrm{F}$ is not Tnehrhma and say two words generous * and lower them c Humiliation of mercy and the Lord said mercy to them as my Lord raised me as small] \{Isra: 23-24\} (). "It is the divine, immortal matter of a Muslim in the form of an inevitable judiciary, there is no escape from it and no modification of it," and your Lord decreed that you should only worship him and his parents with charity], and it is for the tight link between the worship of God and the loyalty of the parents, The reformers and moralists will one day reach their destination

And says: [spent your Lord that you worship none but Him and dutiful to your parents either they reach you have old age, one or both do not say to them, F and Tnehrhma say two words generous, and lower them the wing of humility through mercy, and say the Lord has decreed that you worship none small] God ordered us Y good deal if they We have, in our care and protection, in a gentle manner, dripping delicacy, and smoothness [Either you get old, one or both of you].

Beware, beware that you do not complain or be bored of them, or come out from you with a word that touches their feelings [then do not say to them a pest and do not spoil them, and say to them a generous saying, that the spirit of God is the same as the state of mind, that they will be considerate of the religion, that they will be considerate of the state, that they will be considerate of the religion, that they will be considerate of the state, that they will be considerate of the religion, that they will be sensitive to the state of consciousness, that they should be sensitive to the state of consciousness, that they should be sensitive to the state of mind, that they should be considerate of the state, that they should be considerate of the religion, that they will be considerate of the state, that they will observe the state of mind, that they should be aware of the state, that they will be considerate of the state, that they will be considerate, and that they will be aware of the status of God, who will be sensitive to the status of God, that they will be considerate of the state, that they will be considerate, And literature and companionship in dealing with parents at this age . 
[And lower the wings of humiliation from mercy and say the Lord, have mercy on them as my Lord raised me small] "That is, because your side is to them and subject them, so that you do not abstain from something that He loved.

The Qur'an evoked the feelings of the Muslim person to better deal with his parents with sincere righteousness and mercy, and singled out the mother for more righteousness and communication, because of the pain and troubles he endured in pregnancy and breastfeeding, the Almighty said: [And we commanded man With his parents, his mother carried him frailly with weakness, and he separated him in two years, to thank me and your parents for my destiny.

" And the world may accept the child, and generate income for him other than livelihood, so that his treasures are filled with money, and the beautiful wife and the innocent child occupy it. In a way out of all of this, because he is in constant contact with the generous source of wealth from the high, wise, directives of Islam, it is that he hears the chanting of the Messenger, r: (You and your money to your father) (), and this prophetic literature is shaken to its existence, and it opens to the delegation of guidance itself, so if it is filled with righteousness and love And giving, and if he is at the deliverance of disobedience and infallibility, and if he is truly as the Messenger of Islam wanted him to The fact that: He and his money to his father .

And the Prophet, may God bless him, extends his generous directives to the heyday of humanity, as he recommends the righteousness of the parents and charity to them, even if they are different from the religion of Islam. I said, wishing to be separated from my mother, who said yes to your mother's prayer

A true Muslim, aware of these Quranic directives and prophetic gestures, cannot help but be among the most righteous of his parents, and one of the best in dealing with them.

One of the greatness of Islam, and the preservation of that strong relationship, is that he commanded the good relationship with the people of the parents 'parents and placed them in the highest ranks of righteousness .

\section{The second topic: Islamic directives in treating the wife}

Marriage is a comfort for the heart, housing, and stability for the conscience, based on affection, intimacy, mercy, tolerance and counseling, to create a Muslim family that establishes God's law.

The Almighty said: [And among his signs is that he creates for you wives from yourselves, that you may dwell in them.] And make affection and mercy among you for your sake.

It is the societal structure in the closest and most common thing; God made it between the two spouses to enjoy tranquility and stability, in the house of a marital marriage, full of love, affection and communication. Ibn Katheer said: "That is, to make it familiar and live with it

And marriage is the main pillar, and the first pillar of mutual compassion between the spouses. Rather, he preferred the supererogatory rituals of worship as Ibn Al-Qayyim said: "He inferred the preference of marriage over giving up to the superlatives of worship that God Almighty $\square$ chose to marry his prophets and messengers, and the Almighty said: [And we have sent a messenger from us through you wives and offspring, and he messenger to come to any but God willing, for each book] \{Thunder: 38\}, said the right of Adam: [and make them her husband to live to] \{custom: 189\}, and cut into Clemh ten years in the care of the sheep wife's dowry And $m$ The science of the amount of these ten years in the superfluous acts of worship .

"And among the Islamic axioms that need neither mentioning nor repetition, that a woman in the tradition of Islam is a human being who has a human spirit of the same kind from which the spirit of a man [created you from one soul] $\{\mathrm{Al}-$ Zumar: 6 \}. The human entity has all the rights directly related to this entity

And the relationship between the spouses is a pure advocacy relationship, "then each party must understand the other in depth through discussion, inquiry and speech" (). If the husband enters his home, he accepts his caring face, and his kind heart, he initiates his wife and children with the best greetings, which God described as a good blessing from He has where he said: "If you enter into houses, greet yourselves with a good blessing from God." (Al-Nur: 61). Al-Zamakhshari says: "And they began peace to its people, who are of you a religion and kinship [salutations from Allah's blessings are good blessings] that is, fixed by his command, lawful from his authority 
Starting peace between spouses is one of the most important methods of emotional construction, and "emotional building methods between spouses are among the most important characteristics that distinguish the marital group from other small groups, as the dynamics of marital interaction are based on emotional communication between the spouse

Great Islam has commanded good dealing with the wife, fairness and honor, even if she hates her, and this was represented in the Almighty saying: [and associate with them well-known, for if you hate them, then it is difficult for them to disobey all of them. Mixing and socialized women with the knowledge that they courted them in the article and beautified them with them in the action .

"The doctrine of matrimony in Islam is greater than small emotional freaks, and it is postponed by the pressure of a frenzied animal tendency, and in a Muslim the right to virility, nobility, tolerance, endurance and capacity The chest and highness of creation is what causes him to rise in his dealings with his wife, who hates, very far from the whims of beasts, and the greed of the merchant, and the empty nonsense.

And because the man in the house is responsible for directing everyone, he had to lead the ship of life in his family towards the shore of safety, guidance and guidance, and not weaken in front of the sedition of women, God imposed greater than the affection of women, the Almighty said: [Say: If your forefathers, your children, brother, and brother, and your brother Aqtervtamoha trade concerned about the depressed housing Tradwnha I love you from Allah and His Messenger and Jihad in the process of Fterbesoa until Allah brings His command and Allah does not guide the evildoers Alto It includes: 24 ]

\section{The third topic: the relationship of a Muslim with his children}

The relationship of parents with their children is one of the most important and the most beautiful relationships, especially if it is based on respect, love and concern for the satisfaction of God, the relationship between parents and children is very important, especially in this age, as the way our children think is affected by advanced technology and various events that surround our world, as you play The media plays a big role in how children think and speak.

"Communication processes are the basis of human relations and human understanding, and they play a prominent role in the process of teaching and learning." (Especially if education and dealing with children in their childhood from an early age, "childhood is the basis for building the human personality, its first start, and the formation of the human being is based Strong and healthy, from different aspects; physical, health, psychological, social, cultural, and economic aspects, and adults are usually affected by what they are used to in childhood, and a person cannot forget that stage with its advantages or positives, and what it is that there are pitfalls or pitfalls or Cons, remain a memory The events of childhood well-establish Therefore, it was necessary for the head of the family to realize how important it is to communicate with his children since childhood, "The family has a large and important role in relation to teaching the child methods of dealing with others, and it also has a role in modifying behavior".

"Here the role of parents and the family appears, as the primary task of the family is still raising children. In the family, the child develops his identity and learns to deal with others".

Children need an intense, wise effort to prepare them properly in order to elevate and advance society. "One of the most important educational methods for the Muslim family is preparing children to play the role assigned to them in the process of civilized advancement of their nation, so a kind of correction of concepts and control of intent and making their slogan in life" say My life and my death are to God, Lord of the Worlds.] \{Al-An'am: 162\}.

\footnotetext{
“The children are the man's life in his life, his joy in his life, his life is in his life, they have life, and after them God hopes are suspended, and with their blessing he brings sustenance, and mercy descends, but this is all dependent on the good raising of children, and the good upbringing that makes them elements of good, And factors of righteousness, and sources of happiness, for the availability of man in all of his children were truly the adornment of this worldly life "() as God Almighty described them by saying: [Money and children are the decorations of this worldly life] \{Cave: 46$\}$ " Money and children are beauty and pleasure for you in this worldly life They are its strength.
}

And in Article (93) of the Family Charter in Islam, it says: "The family is the child's embrace and natural environment necessary for his care and upbringing, and it is the first school in which a child is raised on human, moral, spiritual, and religious values. 
The social interaction with the children must be based on the rule of not differentiating between the male and the female, God Almighty says: "O people, fear your Lord who created you from one soul, and created a woman from him.

It is the greatness of Islam that he commanded the parents to consult with each other, for the sake of weaning him when he was young, and this was embodied in the Almighty saying: [If they wanted a separation from their consent and consulted, then there is no wings over them] \{Al-Baqarah: 233$\}$.

Interacting with and caring for children stems from explicit texts in the Holy Qur'an, so that a conscious Muslim can realize his greater responsibility towards his children, and that includes the Almighty saying: "O you who believe! Throw your souls and your people, and the fire and the fire " 6 ".

Al-Baqai says: When a person was a shepherd for the people of his household responsible for his flock, the Almighty said: [And your family] are women and children.

\section{The fourth topic: the relationship with relatives and wombs.}

Righteousness, benevolence, and good dealing with parents, wife, and children are not limited only, but include those of kinship and wombs, to deliver as much good as possible to them, and pay as much evil and misfortune as possible for them and give them their rights that God Almighty has decided in his book, and he said: And there is no wastage of waste] \{AlIsraa: 26\}, and Al-Zamakhshari mentioned in his scout this meaning, and he said: "[And this relative came to his right], and he commanded other than the relatives after the recommendation of them, and they should fulfill their right: and their rights are as if they were confused About earning .

And its legal ruling is a duty but rather one of the most obligatory duties, "And it is not a sign of the gracious hospitality of Islam from the womb of that wonderful image drawn by the Messenger of God $\square$ to the womb, rises in the hands of God $\square$ in the large arena in which God created the creation, so she seeks refuge from her herd, and God answers her $\square$ her question Faisal, who arrived and cut off from it. And from the hadith of Abu Hurairah $\square$ He said: The Messenger of God said $\square$ (God created the creation, and when he finished it, the womb rose, and I took the righteous grace of God, and he said to her: Mah, she said: This is the position of the one who gives you a break He said: Would you not accept that I come from you and cut off your pieces? She said: Yes, Lord, he said: So) Abu Huraira said: (Read if you like: So will I "If you take care of yourself on the earth and break your wombs" (\{Muhammad: 22\}) (). It is an indication of family interaction and cohesion, the continuous follow-up of their affairs and conditions, and giving them some time to present and discuss their problems away from unilateralism and introvertedness, and it is also one of the piety of God Almighty, for God Almighty said: "And fear God, who is asked by God," Al-Zajaj: "Meaning and fear the wombs to cut it off

The Qur'an also decided as a ladder of priorities in meeting the spiritual, physical, and social needs of the soul. He began with the greatest of what the Muslim worshiped his Lord - monotheism - and then began directing human behavior, according to the relationship of kinship; then he began with parents, then praised the siblings of the kinship and said: [Worship Allah, and do not associate Do something good and to the parents, and give them kinship ...] \{Women: 36\}.

And the Messenger $\square$ invites us to interact in all its forms, as it results in love in the family, good manners, generosity in money, good breath, building social morals, and strengthening the bonds of society where he said: (Learn your lineage, then pray your wombs, and God is to be between the man and between His brother is the thing, and if he knows what is between him and him from inside the womb, I will distribute it for his violation).

The texts that call for a link to the wombs have been exhausted, and warns of his estrangement from it, on the authority of Anas bin Malik, that the Messenger of God $\square$ said: (He who loves to spread his mercy to him, and wakes up to him in his impact, so that he may have mercy on him) so communication with the wombs and relatives is one of the reasons Extend livelihood and extend life.

It was also narrated from the hadeeth of Thawban $\square$ : (It does not increase in life except the righteousness of parents, and does not increase in livelihood except in relation to the womb).

"As we have seen the connection of the womb with blessing on its owner in his livelihood and age, and mercy from God overwhelms him in this world and his last, and brings to the people's love for him, and praise him, we find in return the uterine estrangement of misfortune over its owner and misfortune, and a detestation to him from God and people, and a distance from him in heaven in Decision was made, according to the boycott of the womb, with misfortune and misery and deprivation, to hear the Messenger's words $\square$ in it (he does not enter Paradise, to cut off a wom 
Good dealing with the ties of wombs and relatives is a duty for a Muslim to meet even if they do not pray him, according to the Prophet's saying $\square$ : (The linker is not equivalent, but the linker that if his womb is cut and connected)

"From here the true Muslim was continuing his womb in any case, always looking for his Lord's pleasure in this connection, never rising from ignorances, foolishness and abuses, which appear from time to time with those of his kinship, exposed to all the small and insignificant things that occupy the young of the people, and the tensions from them appear

\section{The fifth topic: The Muslim and his relationship with the people of his neighborhood and his neighbors}

The good deal with the people of the neighborhood and neighbors, is from Allah and His Messenger where God $\square$ said in his book Aziz: Worship Allah and join none with nothing to parents, kinsfolk, orphans, the needy and the neighbor of kin and the neighbor side and Saheb says ... \{ \{women: 36\} " And the neighbor who is near: the one who is related, who is the relative, and the neighbor who is near you, the one who is far from you, and the one who is by the side, said: What is meant by the companion in traveling, or from his companion and know him, even for a short time.

Neither the neighbor is the adjacent, or the near-distant, "and the neighbor who is the relative and the one who is called by the name of the neighborhood with the fact that his house is far. This is evidence of the generalization of the neighbors with goodness to them. Whether the homes are close or far apart, and that the neighborhood has a strict sanctuary commanded by it. Response to those who think that the neighbor is dedicated to the adherents without a barrier between him and him, or specialized in the relative without the distant.

Hence the hadiths of the Prophet $\square$ recommends that the neighbor in general is not looking at kinship or religion, stressing the importance of social communication with the neighbor, it came from the hadith of Ibn Omar $\square$, he said: The Messenger of God said $\square$ : (Gabriel still recommends me to the neighbor, until I thought that Seaworth.

The Messenger of God was accustomed to Gabriel's recommendation to urge the honor and benevolence of the neighbor, so that he did not disturb his historical sermon in the farewell argument, in which he compiled the constitutional rules and in which the Muslims 'lives were straightened, from making the neighbor a great space in it, drawing the attention of the great companion Abu Imamah $\square$, So he also thought that the Holy Prophet would inherit it, and that is in his saying: (I heard the Messenger of God $\square$, and he is on the camel's trunk in the farewell argument he says I recommend you to the neighbor even more, so I said that he inherits it).

And from the hadith of Abdullah bin Amr, he said: The Messenger of God said: "The best of the companions is with Allah, the best of them is for their companion, and it is better than him

Umar ibn al-Khattab $\square$ the neighbor counted one of the three who praised the man and he was sentenced to righteousness, where he said: "When the man praises his neighbor, and with his kinship and companion, do not doubt his goodness.

Good treatment with the neighbor, neighbor, and companion is a measure of the goodness of the man, and thus the goodness of the entire nation.

"The Golden Imam dealt with the rights of the neighbor in detail, which must be nurtured and cared for by every Muslim, and performed by him in grace and affection, so that society becomes one family, security and peace prevail, and it is common among its members of love and faith, citing the Holy Qur'an and the Sunnah of the Prophet.

The Prophet lays a foundation for building the Islamic Ummah, and building an Islamic community based on good treatment, support, compassion and sympathy. From the hadeeth of al-Nu`man bin Bashir $\square$, he said: The Messenger of God said: (Like the believers in their affection, compassion, and sympathy as the body if a member complains of it, then the rest of the body is called to him by watching and fever).

Religion is keen on the cohesion of members of the nation, this strange cohesion, for a priori to document the relationship of the neighbor to his neighbor, and evaluate it on the basis of a firm pillar of affection, righteousness, communication and good treatment.

"With this high prophetic guidance, and his sublime guidance in good neighborhood, the pious Muslim knows the right of his neighbor at him at all times. He used to comfort, comfort and support him, and if the Shiites fulfilled his term and comforted his family and did good to him, and he never lost sight of his neighbor's and family's feeling and avoided something that would scratch or hurt this feeling from near or far. He is illuminated by the light of a gift, applying his rulings on himself and his family. 
Is it any wonder - after all this - that a true Muslim be the best neighbor that human societies have known.

\section{The sixth topic: The relationship of a Muslim with his brothers and fellow believers}

One of the most prominent features of the Islamic community is its close association and interaction with each other, characterized by sublime love, devoid of any benefit, pure from all impurity, represented by God Almighty saying: [Only the believers are brothers] \{Al-Hujurat: 10\}, says Makki bin Abi Talib: "Believers are brothers in religion" and al-Samani says: "That is, in succession, mutual support, and compassion" Al-Samani's statement indicates that brotherhood is based on solidarity and compassion on a solid basis of religion

God says $\square$ : [believers and believers and some parents of some enjoin good and forbid evil and establish the prayer and pay Zakat and obey Allah and His Messenger ... repentance $\{71\}$. Al-Razi says in the interpretation of this verse, "Knowing that he is exalted, when he described the believers as the guardians of one another, after which he mentioned the course of the explanation and the explanation for him, and he said: [... they command the favor and forbid the deniers and establish the authority and the authority : 71$\}$, then he mentioned these five things in which the believer is distinguished "(), and these five things are those that embody the call to God a reality.

Sayyid Qutb said in this regard, "The nature of the believer is the nature of the believing nation. The nature of unity, the nature of solidarity, and the nature of solidarity".

It is no wonder that this unique brotherhood, and that eternal vocation, yield a pattern of love, marvelous in its highness, purity, depth and durability, which is what we call love in God.

A true Muslim, who is aware of the matters of his religion, knows that Islam, which called for love and compassion, is the one who forbids hatred, estrangement and desertion, and shows that sincere loving ones do not differentiate between them, the occasional squabbling between them. $\square$ : (There are no two in God $\square$, or in Islam, so the first sin that is caused by one of them separates them) However, Islam did not overlook the nature of the human psyche, and it is subject to the whims of anger and emotional fluctuations in moments of weakness. Harmony, and in that the Prophet says: (It is not permissible for a Muslim to abandon his brother over three nights, they meet to present this and present this, and their goodness that begins with peace) and the sincere and sensitive Muslim who contemplates this fixed text, does not tolerate the migration of his brother and his opponent no matter what Reasons, but he rushes to his handshakes and hand over to him, because the best of them comes from He continued with his brother, starting with peace.

And the Muslim person is social from the high level, in accordance with the provisions of his true religion, and by what he represents from his noble noble caliphs, which he called for, and urged creation by them in the areas of social interaction.

And the personality of the Muslim who was enlightened by the guidance of the Noble Qur'an, and I found from the manhole of the pure prophetic Sunnah a unique personality. It is not measured by the social personality brought up by contemporary positivist systems, nor by the ancient laws that are used in framing philosophers and thinkers.

She is a high-class social figure, created by a very large group of morals, uttered by the texts of this true religion from a noble Qur'an and an honorable hadith, and made creation by it a religion that one is rewarded for, and held accountable for leaving, so she was able to make the true Muslim figure a unique example of a high-class social man Polite, clean, charitable, pious.

The researcher looking for these texts in their manifestations, to be amazed by their abundance, absorption, comprehensiveness, and accuracy, as she did not leave an aspect of life except that I addressed it, and her speech in it said, referring to the high and luminous meeting that Islam wanted the Muslim to rise to, and that he is undoubtedly sublime to it, when The truth of Islam settled in his heart, and the gift of ablution spread in the aspects of himself, mixing with his screen his soul and perpetuating the values of his being.

And the strength of the components of the Muslim's social personality, his standing at the limits of God in his social behavior and his treatment of people.

It is from this great origin of the origins of the Islamic faith that the social morals of the devout Muslim show a subtle in his behavior, and on this solid foundation the true Muslim establishes his social relations with people. 
The broad rule from which a Muslim preacher starts his interaction with society is the saying of God $\square$ : "Call to the path of your Lord with wisdom and good preaching, and argue with them with what is best, and the best of all:" With kindness and kindness, and choosing the appropriate time for the sermon that they want to preach, so that souls can accept it, and benefit from the good that it contains. The Messenger is a doctor who carries medicine to minds, hearts, and spirits, hence his difficult and arduous task, with which he needs effective insight, implemented into hidden The human soul, laying hands Here is the disease, then choose from what medicine heals the illness, and goes with the disease "[... and argue with them that it is the best ...] \{Al-Nahl: 125\}, meaning: their pilgrims, and their viewers of the argument and the statement, and it is said: with softness".

And softness is another basic rule in the interactive process of the Almighty saying: "And as a mercy from God, you will have for them. Forgive them, and consult them in the matter, knowing their opinions.

"It is an immortal saying, and a steadfast resident constitution, for every preacher who addresses the call of people to the guidance, as he must improve the care of their hearts, and follow the path of kindness, decency, and softness, even if he was called from unjust tyrants, and this is what God provided him with his prophet Moses $\square$ and his brother Aaron while Send them to Pharaoh [Go to Pharaoh, for he has overwhelmed* so say to him, saying soft, so that he may remember or fear: That God says:“ May God protect you. How did he accompany you with someone who says: You are God And the Prophet $\square$ said: "It is forbidden to burn every easy soft loaf that is close to the people." What good is greater than a creation that one possesses so that it has protection from fire? And the Muslim man who seeks to have his interaction with the people and with the believers must have a positive, effective interaction characterized by the height of vigor. Virtues until you lift it from the lowest perihelion circuits to the highest stations of glory and affirmation It must also be characterized by patience for the Almighty saying: [Patience be beautiful patience] \{Al-Maarij: 5$\}$ “ And it is proven that whoever wants to mix with creation must have much patience, "People were created for assembly not for solitude, and for Not for long relationship antipathy. To cooperate is not unique to every one of his life facilities

A Muslim must be tactful in his call, light-hearted and profoundly clear, not subject to offense to his community, regardless of what was represented by the saying of God $\square$ : [And do not deny those who call from God's sins, but they cursing God as an enemy without the knowledge of: 108) "The advice is heavy, so do not send it to a mountain and do not make it controversial, and the facts are bitter, so borrow it for the lightness of the statement.

Among the interactive duties in the Muslim community is the sick clinic, which is not preferable or voluntary. Rather, the Muslim is to communicate with his sick brother by visiting him and filling his feelings to implement the command of the Messenger of God $\square$ who said: (Feed the hungry and return the patient and release the ani).

And an important matter for a Muslim to maintain is the disclosure of peace among people, in the words of God Almighty: "[And when you live with a salutation, they live with the best of it or respond to it." \{Women: 86 Her response, and came to the interpretation of this verse: "[And then You are greeted with salutations] If He greeted you with peace in peace [live better or better than it or return them] and spread it in a better way than it in the increase over the people of your religion

And the formula of peace as we know it, beloved $\square$, where he said: (God created Adam in his image and he was sixty cubits long, so when he created it he said: Go and greet those people, and they are angels sitting, so listen to what they live in you, so they greet you and salute your offspring. He said: So he went and said: Peace be upon you And they increased it: and God's mercy.

\section{CONCLUSION}

Praise be to God, whose grace is righteous, so praise be to God a lot that helped me to complete this research, and the researcher has concluded through him a set of results and recommendation.

\section{First the results}

1) The Islamic religion is a true and tolerant religion that calls for family building and fights disintegration.

2) Someone is keen to distort the image of Islam and Muslims and to show it as a religion of demolition and terrorism.

3) encourages family cohesion by making it a cult associated with reward and hereafter.

4) Islam has dealt with family relations, even with non-Muslims.

5) The Muslim personality is a sophisticated social personality, created by a very large group of morals, which were pronounced by the texts of this true religion from a noble Qur'an and a noble hadith, and it made morality a religion that one is rewarded for and held accountable for leaving. 
6) Righteousness, benevolence, and good dealing with parents, wife, and children are not only limited, but also include those with relatives and wombs, and delivering as much good as possible to them.

7) Islam raised the position of the parents, to a level that humanity did not know in any other than this religion, the true Islamic religion, where God made him $\square$ in the rank that follows his right - Glory be to Him - in monotheism, and made the consent of the parents after God's approval.

\section{Second: Recommendations}

1) researcher recommends preachers to focus on the bright side of this true religion, especially in the West.

2) Attention to publishing research that shows Islam in its true form in English or other foreign languages, especially with the familial disintegration of the West.

3) Focusing on comparing the Islamic religion's view of family and society, with the West's view of them.

- The Holy Quran

\section{SOURCES AND REFERENCES}

1) Ibrahim bin Al-Sari bin Sahl, Abu Ishaq Al-Zajaj, the meanings of the Qur'an and its syntax, Beirut, the world of book .

2) Ibn al-Jawzi: Jamal al-Din Abu al-Faraj Abd al-Rahman bin Ali bin Muhammad al-Jawzi, increased the path in the science of interpretation, the investigation of Abd al-Razzaq al-Mahdi, Beirut, Dar al-Kitab al-Arabi.

3) Ibn al-Qayyim Muhammad bin Abi Bakr bin Ayoub bin Saad Shams al-Din Ibn Qayyim al-Jawziyyah, Bada'i alUdaed, Beirut, Lebanon, Arab Book House.

4) Ibn Hibban, Muhammed bin Hibban bin Ahmed bin Hibban bin Muadh bin Maabd, Al-Tamimi, Al-Ihsan in the approximation of Sahih Ibn Hibban, The Investigation of Shoaib Al-Arnaout, Beirut, Al-Risala Foundation, 408 AH - 1988 AD.

5) Ibn Ashour: Muhammad al-Tahir bin Muhammad bin Muhammad al-Tahir bin Ashur al-Tunisi, "Editing and Enlightenment" Editing the Good Meaning and Enlightening the New Mind from the Interpretation of the Glorious Book", first edition 1984 AD, Tunisian Publishing House - Tunisia.

6) Ibn Katheer: Abu al-Fedaa Ismail bin Omar bin Katheer, The Great Interpretation of the Qur'an, Sami bin Muhammad Salama investigation, Edition: 2nd 1420 AH - 1999 AD, Thebes House for Publishing and Distribution.

7) Abu Al-Abbas Ahmed Bin Muhammad Bin Al Mahdi Bin Ajeeba Al-Hassani Al-Anjari Al-Fassi Al-Sufi, The Long Sea in Interpreting the Glorious Qur'an, Achievement by Ahmed Abdullah Al-Qurashi Raslan, Cairo, published by Dr. Hassan Abbas Zaki

8) Abu Muhammad Mahmoud bin Ahmed bin Musa bin Ahmed bin Hussein al-Ghettabi al-Hanafi Badr al-Din alAini, Mayor of Al-Qari Sharh Sahih Al-Bukhari, Beirut, House for the Revival of Arab Heritage.

9) Abu Muhammad Makki bin Abi Talib, guiding to reach the end in the science of the meanings and interpretation of the Qur'an, and its sentences, and sentences of the arts of its sciences, achieving a set of university theses at the College of Graduate Studies and Scientific Research - University of Sharjah, publisher: Book and Sunnah Research Group - College of Sharia and Islamic Studies - University of Sharjah, supervised by a. D: Witness AlBusheikhi.

10) Ahmed Fayez, The Constitution of the Family in the Shadows of the Qur'an, Al-Resala Foundation.

11) Iqbal Muhammad Bashir, and others The Dynamics of Family Relationships, The Modern University Office.

12) Akram Mustafa Morsi, Muslim family in the contemporary world, Ministry of Awqaf and Islamic Affairs of the State of Qatar.

13) Imam Al-Dhahabi, Explanation of the Book of Rights of the Neighbor, Investigation of Ali Ahmed $\mathrm{Abdel-Al}$ Tahtawi, Lebanon.

14) Al-Busairi, a creation brought together by his lexicon, which he called "the title of time with translations of elders and peers." And he has many good categories, died 885 AH. See: Al-Suyuti: Abd al-Rahman ibn Abi Bakr, Jalal al-Din al-Suyuti, organized by al-Aqyan in notables, investigation by Philip Hitti, Scientific Library - Beirut.

15) Al-Khazen: Aladdin bin Ibrahim Abu Al-Hassan, the interpretation of the meanings of the download, the realization of the correction of Muhammad Ali Shaheen, Beirut, Dar Al-Kutub Al-Alami.

16) Dalia Moamen, Family and Family Therapy, Dar Al-Sahab for Publishing and Distribution.

17) Dalia Moamen, Family and Family Therapy, Dar Al-Sahab for Publishing and Distribution.

18) Al-Razi Ibn Abi Hatim, Interpretation of the Great Quran by Ibn Abi Hatim, Investigation of Asaad Muhammad Al-Tayyib, Nizar Mustafa Al-Baz Library - Kingdom of Saudi Arabia, 3rd edition.

19) Al-Zamakhshari, Abu Al-Qasim Mahmoud bin Amr bin Ahmed, Al-Zamakhshari Jarallah, Unveiling the facts of the mysteries of the download, Beirut, Dar Al-Kitab Al-Arabi, 3rd floor. 
20) Suleiman bin Ahmed bin Ayoub bin Mutir al-Lakhmi al-Shami Abu al-Qasim al-Tabarani, The Great Dictionary, Investigated by Hamdi bin Abd al-Majid al-Salafi, Cairo, Ibn Taymiyyah Library.

21) Samarkandi: Abu Laith Nasr bin Muhammad bin Ahmed bin Ibrahim Al Samarkandi, Bahr al-Ulum, first edition.

22) Al-Shaarawy, Mohamed Metwally Al-Shaarawy, Al-Khawater, Akhbar Al-Youm Press, 1997.

23) Abdel Karim Younis Al-Khatib, Quranic Interpretation of the Qur'an, Cairo, First Edition, Dar Al-Fikr Al-Arabi

24) Abdullah bin Abbas - may God be pleased with them both, enlightening Al-Muqbas from the interpretation of Ibn Abbas, Lebanon House of Scientific Books.

25) Judge: Hussain bin Muhammad Al Mahdi - Member of the Supreme Court of the Republic of Yemen, hunting of ideas in literature, ethics, judgment and proverbs, revised by: Professor Allama Abdul Hamid Muhammad Al Mahdi, first edition 2009 AD, this book was registered at the Ministry of Culture, at the Book House with a deposit number (449), Lawyer Library: Ahmed bin Muhammad Al-Mahdi.

26) Muhammad bin Ibrahim Al-Hamad, Bad Morals, Saudi Arabia, Publications and Scientific Research Agency.

27) Muhammad bin Ismail Abu Abdullah Al-Bukhari Al-Jaafi, Al-Masnad Al-Sahnah Al-Sahih, abbreviated from the matters of the Messenger of God $\square$ and his Sunnah and his days tagged with Sahih Al-Bukhari, investigation by Muhammad Zuhair bin Nasser Al-Nasser, House of Life (illustrated by the Sultanate by adding the numbering of Muhammad Fouad Abdel-Baqi), 1422 AH.

28) Muhammad bin Jarir bin Yazid bin Katheer bin Ghaleb Al-Amali, Al-Bayan Mosque in the Interpretation of the Qur'an. Achievement: Ahmed Muhammad Shaker, Beirut - Lebanon, Al-Resala Foundation.

29) Muhammad Ali Al-Sayes, Professor Al-Azhar Al-Sharif, Neal Al-Maram from Interpretation of Verses of Rulings, Investigated by Naji Suwaidan, The Modern Library for Printing and Publishing.

30) Muhammad Mahmoud Al-Hijazi, The Clear Interpretation, Beirut, New Generation House.

31) Muslim, Muslim ibn al-Hajjaj Abu al-Hasan al-Qushairi al-Nisaburi, the short and correct datum for transmitting justice from justice to the Messenger of God, known as Sahih Muslim, by Muhammad Fuad Abd al-Baqi, Beirut, House of Revival of Arab Heritage.

32) Naji Rajab Sukkar, Jamil Omar Nashwan, Educational Administration in the light of contemporary trends, Dar Al-Manara Press.

33) Al-Hashemi, The Muslim Personality as Formulated by Islam in the Book and Sunnah, Dr. Muhammad Ali AlHashemi, Dar Al-Bashaer Al-Islamiyya, Edition: Tenth, 1423 AH - 2002 AD.

34) Ibn Taymiyyah Al-Harrani Al-Hanbali Al-Dimashqi, Al Nabawat, Investigation by Abdulaziz Bin Saleh AlTawaian, Riyadh, Saudi Arabia, Adwaa Al-Salaf, 1st edition, 1420 AH / 2000 AD.

35) Wahba Al-Zuhaili, the Muslim family in the contemporary world, Damascus, Dar Al-Fikr. 